\title{
Central Nevada Test Area Monitoring Report
}

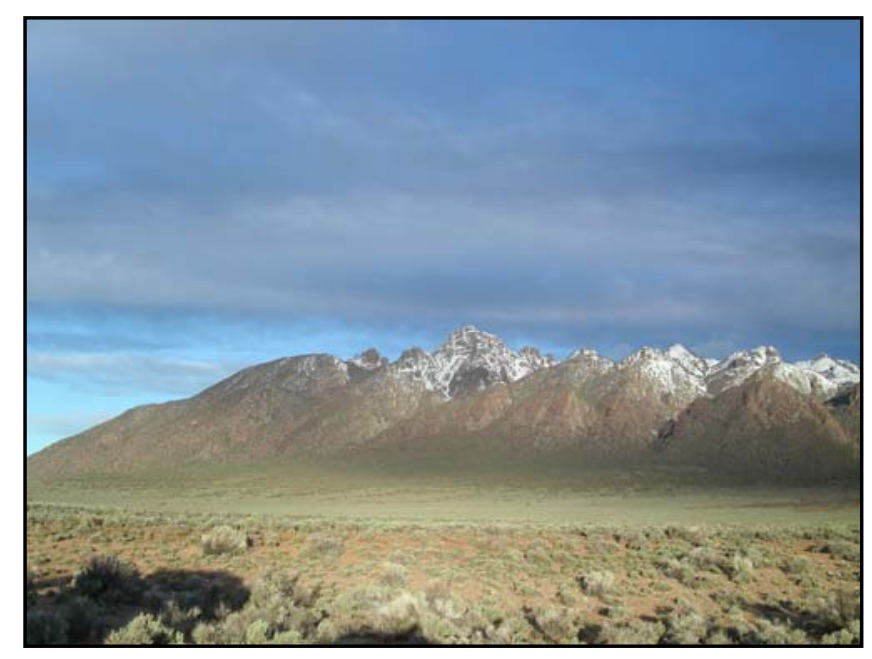

$$
\text { prepared by }
$$

Brad Lyles, Jenny Chapman, John Healey and David Gillespie

\author{
submitted to \\ Nevada Site Office \\ National Nuclear Security Administration \\ U.S. Department of Energy \\ Las Vegas, Nevada
}

September 2006

\section{Publication No. 45222}


Reference herein to any specific commercial product, process, or service by trade name, trademark, manufacturer, or otherwise, does not necessarily constitute or imply its endorsement, recommendation, or favoring by the United States Government or any agency thereof or its contractors or subcontractors.

Available for sale to the public from:

U.S. Department of Commerce

National Technical Information Service

5285 Port Royal Road S/D

Springfield, VA 22161-0002

Phone: 800.553 .6847

Fax: 703.605.6900

Email: orders@ntis.gov

Online ordering: http://www.ntis.gov/ordering.htm

Available electronically at http://www.osti.gov/bridge

Available for a processing fee to the U.S. Department of Energy and its contractors, in paper, from:

U.S. Department of Energy

Office of Scientific and Technical Information

P.O. Box 62

Oak Ridge, TN 37831-0062

Phone: 865.576 .8401

Fax: 865.576.5728

Email: reports@adonis.osti.gov 


\title{
Central Nevada Test Area Monitoring Report
}

\author{
prepared by \\ Brad Lyles, Jenny Chapman, John Healey and David Gillespie \\ Division of Hydrologic Sciences \\ Desert Research Institute \\ Nevada System of Higher Education
}

Publication No. 45222

\author{
submitted to \\ Nevada Site Office \\ National Nuclear Security Administration \\ U.S. Department of Energy \\ Las Vegas, Nevada
}

September 2006

The work upon which this report is based was supported by the U.S. Department of Energy under contract \#DE-AC52-00NV13609. Approved for public release; further dissemination unlimited. 
THIS PAGE LEFT INTENTIONALLY BLANK

$\operatorname{lv}$ 


\section{ABSTRACT}

Water level measurements were performed and water samples collected from the Central Nevada Test Area model validation wells in September 2006. Hydraulic head measurements were compared to previous observations; the MV wells showed slight recovery from the drilling and testing operation in 2005. No radioisotopes exceeded limits set in the Corrective Action Decision Document/Corrective Action Plan, and no significant trends were observed when compared to previous analyses. 
THIS PAGE LEFT INTENTIONALLY BLANK 


\section{CONTENTS}

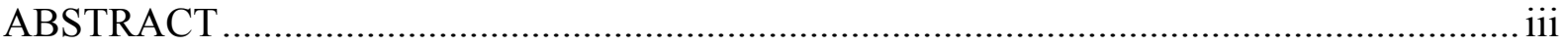

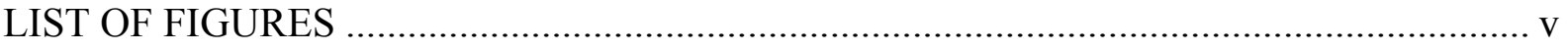

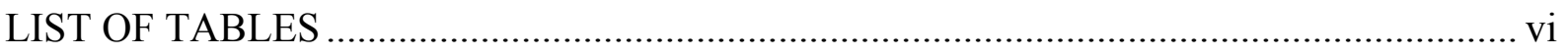

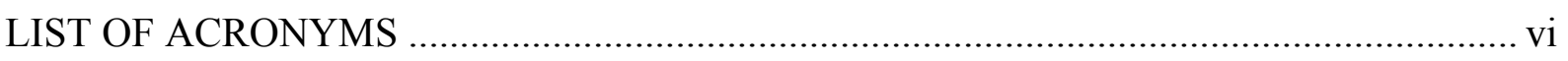

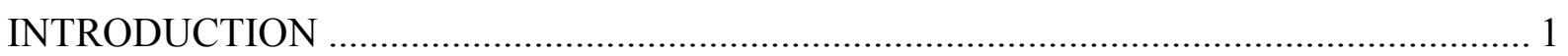

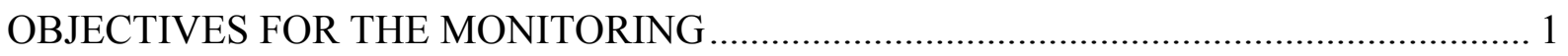

SITE LOCATION AND GENERAL GEOLOGIC SETTING ……..................................... 2

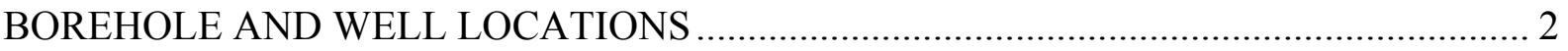

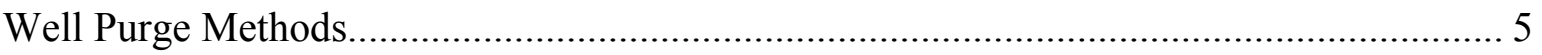

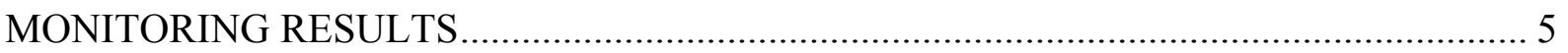

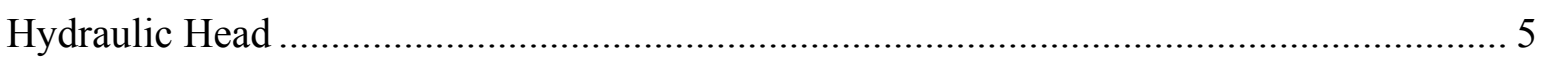

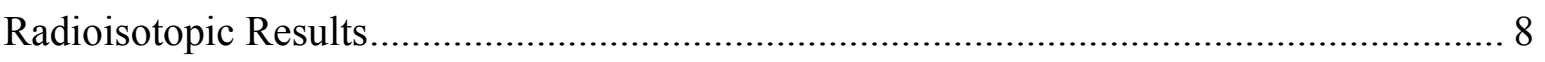

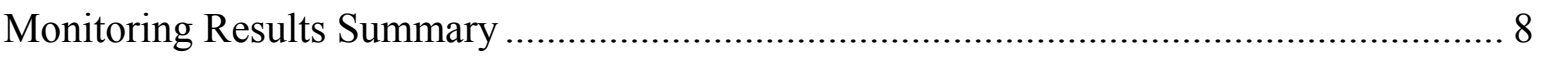

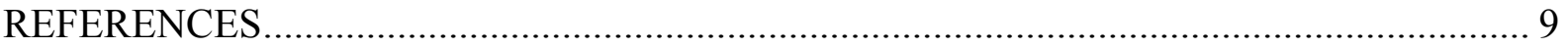

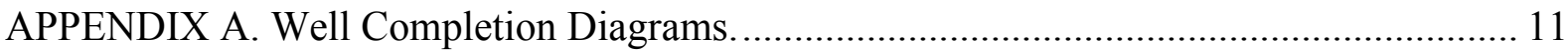

APPENDIX B. Quality Assurance / Quality Control Data..................................................... 15

\section{LIST OF FIGURES}

1. Location of the Central Nevada Test Area in Hot Creek Valley, Nevada........................... 3

2. Location of boreholes near the Faultless underground nuclear test.................................. 4

3. Photograph of the CNTA MV wells; view toward the west along the main access road to the site from Nevada Highway 6. ................................................................ 4

4. CNTA well MV-1 hydraulic head (meters above mean sea level) versus time (solid lines are from pressure transducer readings, periodic water level tags are shown with marker symbols: MV-1, diamond; MV-1 upper piezometer, square; and MV-1 lower piezometer, triangle).

5. CNTA well MV-2 hydraulic head (meters above mean sea level) versus time (solid lines are from pressure transducer readings, periodic water level tags are shown with marker symbols: MV-2, diamond; MV-2 upper piezometer, square; and MV-2 lower piezometer, triangle). .

6. CNTA well MV-3 hydraulic head (meters above mean sea level) versus time (solid lines are from pressure transducer readings, periodic water level tags are shown with marker symbols: MV-3, diamond; MV-3 upper piezometer, square; and MV-3 lower piezometer, triangle). 


\section{LIST OF TABLES}

1. CNTA well location coordinates (UTM-Zone 11, NAD 27, NAVD 29) in meters.......... 3

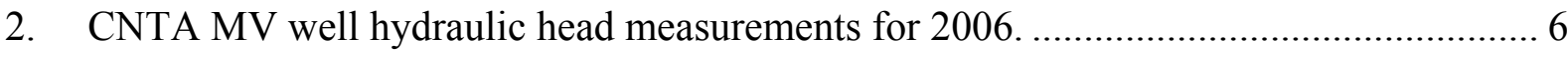

3. CNTA MV well purge data and radiochemistry results. ............................................ 8

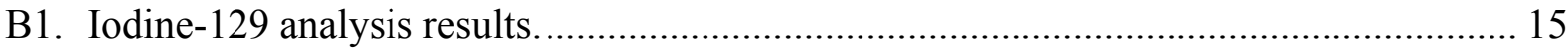

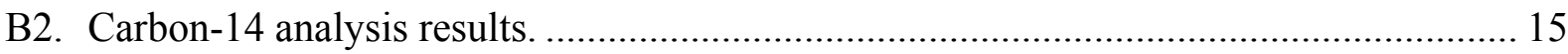

B3. Field parameter stabilization measurements during well purge activities. .................... 16

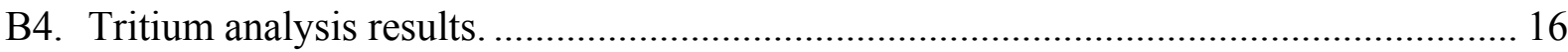

\section{LIST OF ACRONYMS}

CADD Corrective Action Decision Document

CAIP Corrective Action Investigation Plan

CAP Corrective Action Plan

CNTA Central Nevada Test Area

DOE U.S. Department of Energy

EM Environmental Management

FFACO Federal Facility Agreement and Consent Order

MV monitoring-validation

NDEP Nevada Division of Environmental Protection 


\section{INTRODUCTION}

The Central Nevada Test Area (CNTA) was created to provide a supplemental site for underground nuclear tests that could not be conducted at the Nevada Test Site because of ground motion potential in Las Vegas high-rise buildings. One nuclear test was performed at CNTA: the Faultless test, in January 1968, at a depth of $975 \mathrm{~m}$ below land surface. The CNTA was decommissioned as a testing facility in 1973. Activities over the following decades were focused on groundwater monitoring through the Long-term Hydrologic Monitoring Program, operated by the U.S. Environmental Protection Agency.

In the late 1980s, the U.S. Department of Energy (DOE) established an Environmental Management (EM) program to systematically evaluate and remediate locations affected by Cold War activities. For locations in the state of Nevada, EM activities are performed in accordance with a Federal Facility Agreement and Consent Order (FFACO) between DOE, the U.S. Department of Defense, and the State of Nevada (FFACO, 1996). The FFACO prescribes a Corrective Action Strategy for underground nuclear test locations.

For CNTA, the first step in the Corrective Action Strategy was approval of the Corrective Action Investigation Plan (CAIP; DOE, 1999). There were three principal parts to the investigation: collecting data, modeling groundwater flow and contaminant transport, and assessing uncertainty through a Data Decision Analysis. The ultimate objective was development of a contaminant boundary encompassing radionuclide migration through a 1,000-year time period. The investigation primarily relied on information obtained during the nuclear testing time period; new data collection was limited to measurement of water levels and laboratory sorption experiments.

A Corrective Action Decision Document/Corrective Action Plan (CADD/CAP) presented the results of the investigation, the calculated contaminant boundary, a negotiated compliance boundary, and a plan for model validation and monitoring (DOE, 2004). The $\mathrm{CADD} / \mathrm{CAP}$ required drilling three new boreholes around the Faultless test, and installing monitoring wells and piezometers. The boreholes dictated by the CADD/CAP were drilled during spring and summer 2005, and represent the first major subsurface field activity at CNTA since site decommissioning. Drilling and well construction activities are recorded in a well installation report (DOE, 2006). Aquifer testing and additional data collection and analysis are presented in Lyles et al. (2006).

The DOE (2006) and Lyles et al. (2006) reports fulfill the CADD/CAP requirement for an initial report to Nevada Division of Environmental Protection (NDEP) discussing findings resulting from drilling, well completion, and well development. An annual reporting frequency is identified after the initial report to provide NDEP with data regarding the analytes and parameters specified for the CNTA subsurface monitoring program. This report is the first of these annual reports.

\section{OBJECTIVES FOR THE MONITORING}

The objectives of subsurface monitoring at CNTA are to determine compliance with the CAU 443 compliance boundary in terms of contaminant concentrations, and to monitor the hydraulic system relative to the steady-state assumption of the boundary. Three wells are included in the monitoring network for CAU 443. One of these, MV-3, has a primary function for detection monitoring, while the other two (MV-1 and MV-2) have system 
monitoring as their primary function. Despite their different focus, all of the wells will be monitored for hydraulic head and will also have groundwater samples collected for radionuclide analysis.

Analysis of the flow and transport model results indicated that the optimum monitoring well location is due north of ground zero at a depth of 1,075 m (100 m below the working point) (Hassan, 2003). This is the approximate location of MV-3. Hydraulic head is monitored to ensure that the groundwater system continues to behave as predicted in the modeling. As a result, wells are located to the northeast (MV-1) and west (MV-2 of ground zero (in addition to due north) to laterally distribute head measurements; and two

piezometers are located in each borehole to distribute head measurements vertically.

\section{SITE LOCATION AND GENERAL GEOLOGIC SETTING}

The CNTA is in south-central Nevada in Hot Creek Valley (Figure 1). Hot Creek Valley extends approximately $110 \mathrm{~km}$ (70 miles) between north-south-oriented mountain ranges, with the valley width ranging between 8 and $32 \mathrm{~km}$ (5 and 20 miles). West of the valley is the Hot Creek Range, rising to a maximum elevation of 3,100 m (10,200 ft) at Morey Peak. The valley floor elevation varies from 1,575 to 1,830 m (5,180 to $6,000 \mathrm{ft})$. The Faultless site within CNTA is on the western alluvial fan at an elevation of approximately $1,860 \mathrm{~m}(6,100 \mathrm{ft})$. Hot Creek Valley drains southeastward to Railroad Valley in the vicinity of Twin Springs Ranch, though there is little streamflow on the valley floor except during periods of heavy runoff from the mountain streams.

\section{BOREHOLE AND WELL LOCATIONS}

Existing wells and the MV well locations are listed in Table 1. Elevation measurements are to the top of the casing for all wells, except for those listed as "CONC," which is the top of the concrete; the top of concrete is defined as land surface. Water level elevations are measured with respect to a land surface datum.

The MV wells were drilled and completed as prescribed by the CADD/CAP. Each of the MV wells has a primary well string (designated by a "W" on Table 1) completed within a densely welded tuff and outfitted with a submersible pump. In addition, the wells were constructed with two piezometers: one screened in the alluvium (designated by a " $U$ " in Table 1) and one screened in the volcanic section (designated by an "L" in Table 1). Details regarding the drilling and construction of the MV wells can be found in the CNTA well installation report (DOE, 2006).

The MV wells are generally within $0.8 \mathrm{~km}(0.5 \mathrm{mi})$ of well $\mathrm{UC}-1$, nuclear emplacement well (Figure 2); well MV-1 is generally northeast of UC-1, well MV-2 is generally west of UC-1, and well MV-3 is north of UC-1. A photograph of the study area was annotated to show the general location of the CNTA MV wells from the main dirt access road to the site (Figure 3). 


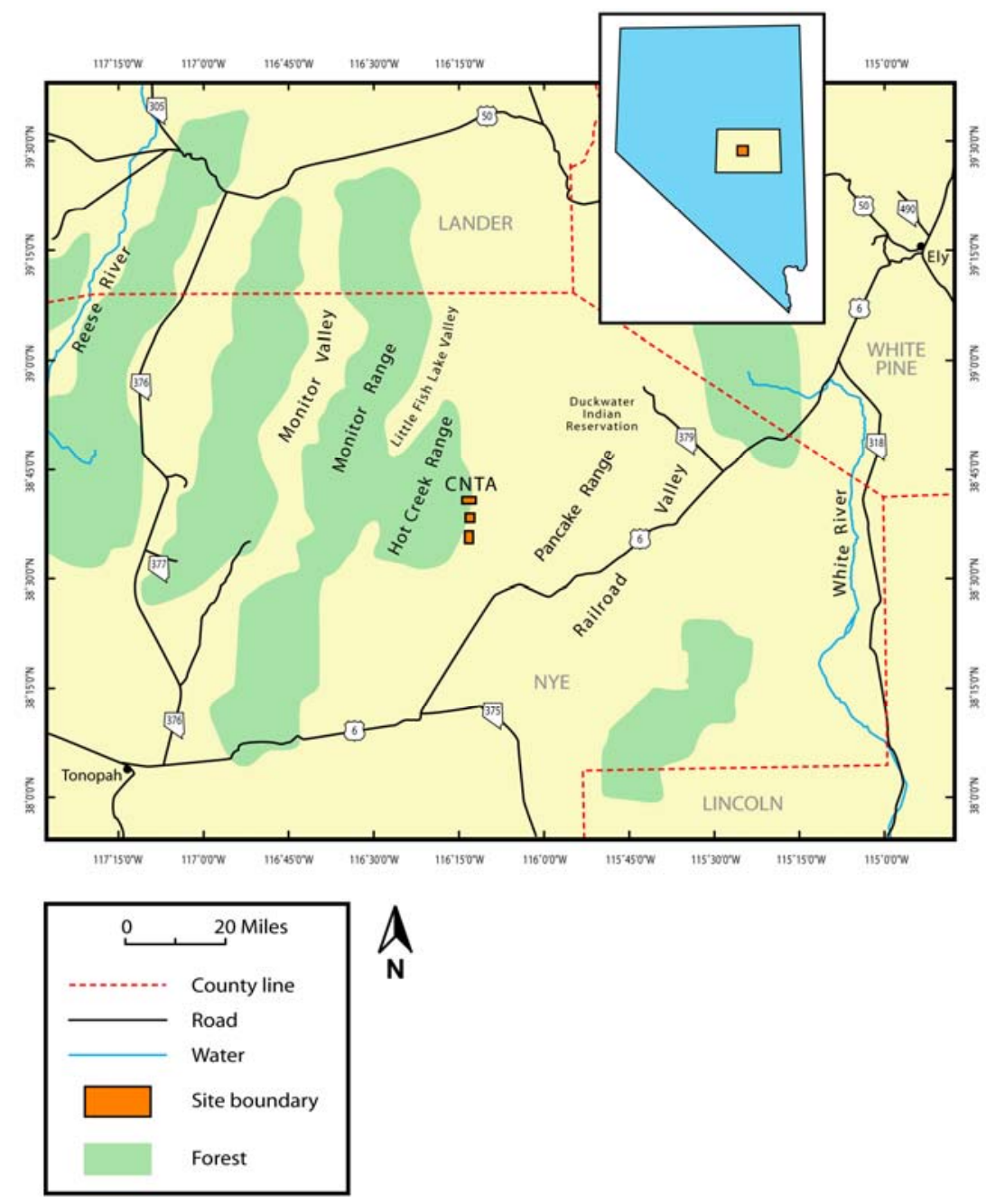

Figure 1. Location of the Central Nevada Test Area in Hot Creek Valley, Nevada.

Table 1. CNTA well location coordinates (UTM-Zone 11, NAD 27, NAVD 29) in meters.

\begin{tabular}{lccc}
\hline \multicolumn{1}{c}{ Station } & Northing & Easting & Elevation \\
\hline MV-1 CONC & 4277003.27 & 568977.45 & $1,849.89$ \\
MV-1 W & 4277003.05 & 568977.31 & $1,850.12$ \\
MV-1 L & 4277002.93 & 568977.35 & $1,850.11$ \\
MV-1 U & 4277002.86 & 568977.56 & $1,850.13$ \\
MV-2 CONC & 4275787.57 & 567575.03 & $1,886.64$ \\
MV-2 W & 4275787.44 & 567574.96 & $1,886.85$ \\
MV-2 L & 4275787.50 & 567574.88 & $1,886.84$ \\
MV-2 U & 4275787.33 & 567575.30 & $1,866.92$ \\
MV-3 CONC & 4276956.42 & 568260.47 & $1,879.70$ \\
MV-3 W & 4276956.30 & 568260.56 & $1,879.90$ \\
MV-3 L & 4276956.36 & 568260.66 & $1,879.89$ \\
MV-3 U & 4276956.48 & 568260.83 & $1,879.91$ \\
\hline
\end{tabular}




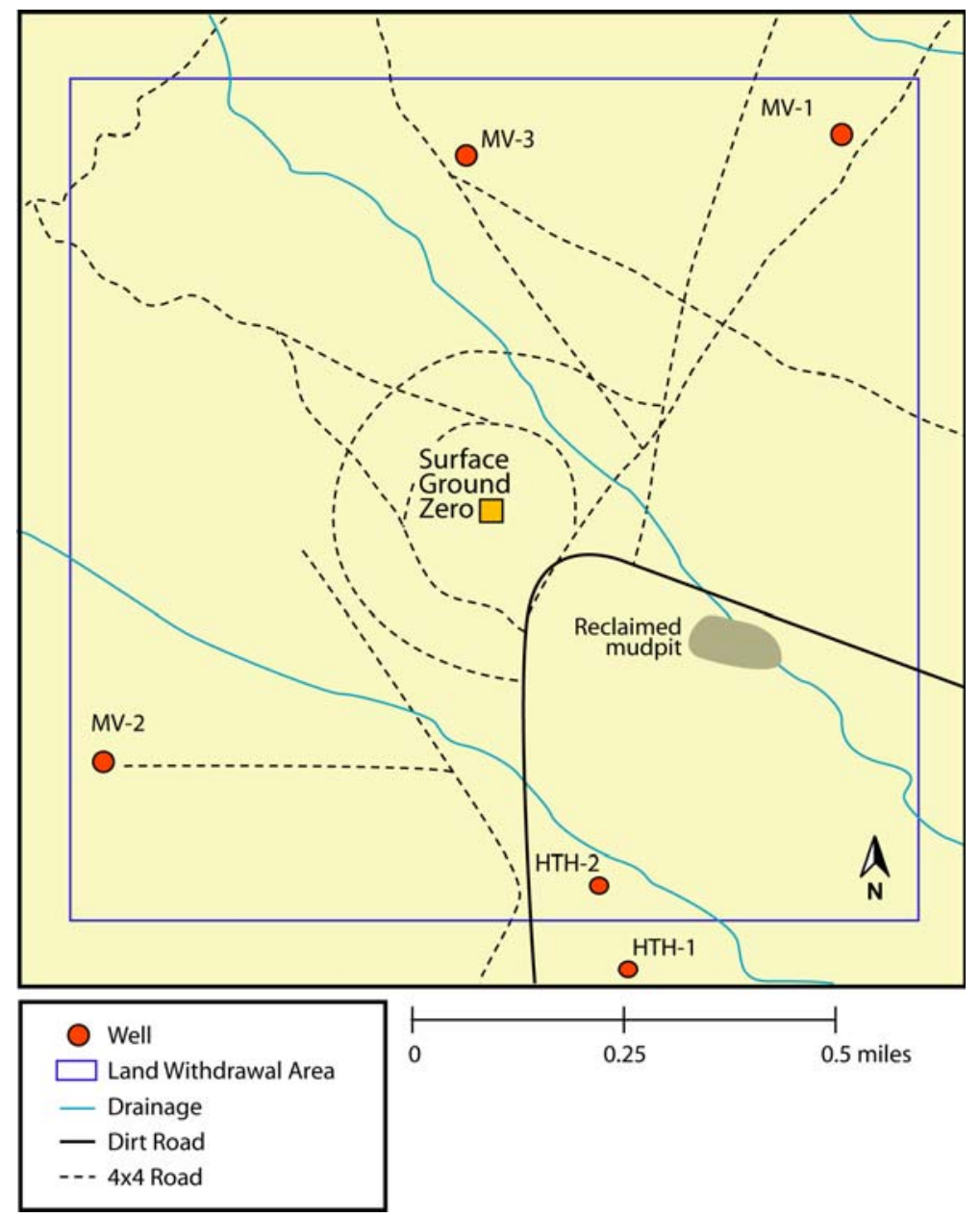

Figure 2. Location of boreholes near the Faultless underground nuclear test.

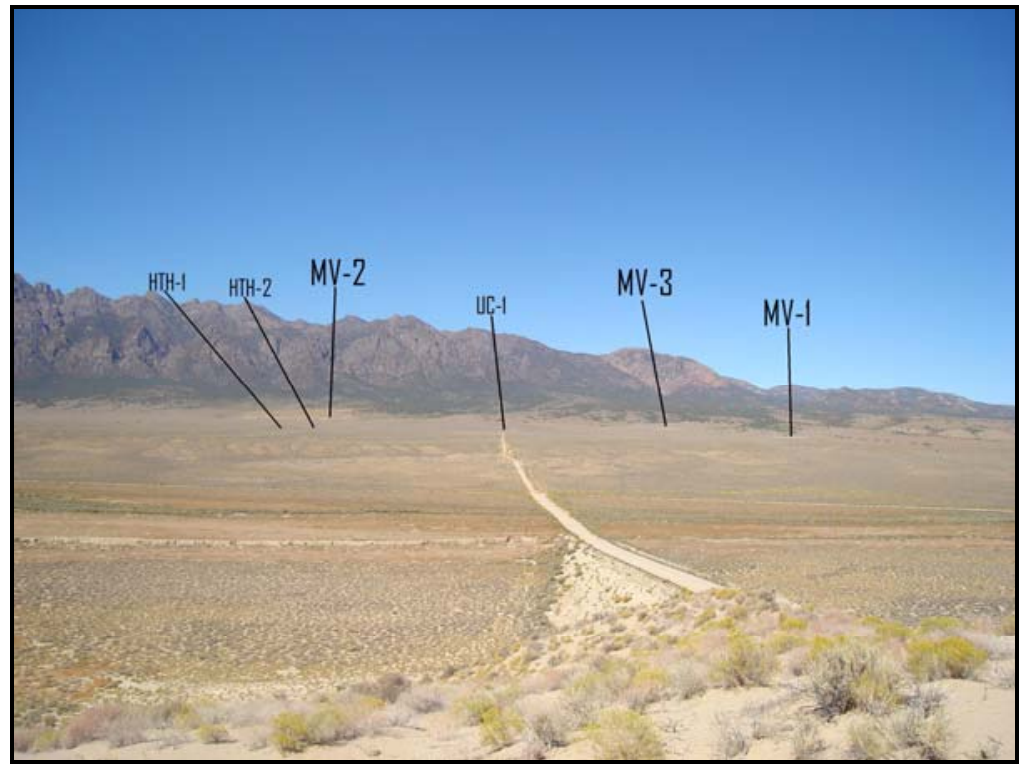

Figure 3. Photograph of the CNTA MV wells; view toward the west along the main access road to the site from Nevada Highway 6. 


\section{Well Purge Methods}

A sample and analysis plan was developed for the CNTA to guide the use of standard operating procedures to assure quality assurance / quality control of the monitoring program. Radioisotopic analyses of carbon, iodine, and hydrogen were performed on water samples collected from the MV main wells, via submersible pumps. Well purging is the process where a prescribed volume of water is removed from the well prior to samples of that water being collected. The purging process is intended to remove water impacted by the well bore environment and to acquire water that is representative of water within the adjacent geologic formation. DOE (2004) states that a purge volume consists of at least one well volume. Purge volumes are calculated according to the DRI Standard Operating Procedure for Well Purging and Collecting Groundwater Samples (DRI SOP.WPGS). The purge volumes for wells MV-1, MV-2, and MV-3 consist of 14,702, 12,066, and 14,770 liters (L) $(3,884,3,188$, and 3,902 gallons [gal]) respectively. In addition to the minimum purge volume, it is required that water quality parameters, consisting of electrical conductivity (EC), temperature, and hydrogen ion activity $(\mathrm{pH})$ of the discharge stabilize prior to samples being collected.

Due to the low production rates from wells MV-1 and MV-3, it is not possible to pump well volumes; therefore, a modified procedure is used to collect representative water samples from these wells. Wells MV-1 and MV-3 are equipped with Grudfos submersible pumps; the pump intakes are set within $15 \mathrm{~m}(50 \mathrm{ft})$ of the top of the well screen, but the pumps are only capable of lifting approximately $518 \mathrm{~m}(1,700 \mathrm{ft})$ of head (well schematics are included in Appendix A). Due to the low yield of these wells, MV-1 pumps for about 2 hours and yields approximately 4,100 L (1,100 gal) before the pump controller shuts off the pump; similarly, MV-3 can be pumped for about 2.5 hours and yields approximately 4,900 L $(1,300 \mathrm{gal})$ before the pump is automatically turned off. Approximately one-third of this water is recovered overnight, based on hydraulic head measurements. Given the observed discharge rates versus time, it takes about 17 minutes to displace the pump column of stagnant water at MV-1 and about 19 minutes at MV-3. Therefore, the procedure used to purge and sample wells MV-1 and MV-3 is as follows: the first day, pump each well for 2 to 2.5 hours during the afternoon and allow the wells to recover overnight; the next day, pump the wells for 17 to 19 minutes to displace the pump column (monitor field parameters) and collect the samples.

\section{MONITORING RESULTS}

As described in the CNTA CADD/CAP, this monitoring program requires the annual measurement of four analytes: hydraulic head, and activities of carbon-14, iodine-129, and tritium. Baseline samples were collected from each MV well in March 2006 as part of the CNTA Drilling and Testing Program (Lyles et al., 2006), and are included here as the starting point of this annual monitoring program.

\section{Hydraulic Head}

Hydraulic head measurements for 2006 are summarized in Table 2; water levels are still recovering from drilling, aquifer testing and sampling activities, as seen graphically for wells MV-1, MV-2 and MV-3 in Figures 4, 5, and 6, respectively. Generally speaking, the upper piezometers have changed little over the year and the main wells and lower 
piezometers are still recovering; it should be noted that the MV-2 upper piezometer was damaged during development and head measurements are highly suspect.

Table 2. CNTA MV well hydraulic head measurements for 2006.

\begin{tabular}{lccc}
\hline \multicolumn{1}{c}{ Well Name } & Date & Time & Head \\
& (m AMSL) \\
\hline MV-1 & $6 / 22 / 2006$ & $14: 16$ & $1,692.8$ \\
MV-1 Upper Piezometer & $9 / 19 / 2006$ & $10: 32$ & $1,695.8$ \\
MV-1 Lower Piezometer & $3 / 15 / 2006$ & $13: 32$ & $1,753.2$ \\
& $9 / 19 / 2006$ & $10: 46$ & $1,753.4$ \\
MV-2 & $3 / 15 / 2006$ & $13: 40$ & $1,801.6$ \\
& $9 / 19 / 2006$ & $10: 39$ & $1,809.1$ \\
MV-2 Upper Piezometer & $3 / 14 / 2006$ & $15: 47$ & $1,781.9$ \\
& $9 / 19 / 2006$ & $16: 40$ & $1,785.9$ \\
MV-2 Lower Piezometer & $3 / 15 / 2006$ & $9: 26$ & $1,776.9$ \\
& $9 / 19 / 2006$ & $17: 02$ & $1,761.9$ \\
MV-3 & $3 / 15 / 2006$ & $9: 15$ & $1,752.7$ \\
& $9 / 19 / 2006$ & $16: 53$ & $1,780.2$ \\
MV-3 Upper Piezometer & $3 / 14 / 2006$ & $12: 25$ & $1,691.3$ \\
& $9 / 18 / 2006$ & $8: 50$ & $1,697.0$ \\
MV-3 Lower Piezometer & $3 / 15 / 2006$ & $10: 05$ & $1,766.8$ \\
& $9 / 18 / 2006$ & $9: 30$ & $1,766.9$ \\
\hline
\end{tabular}

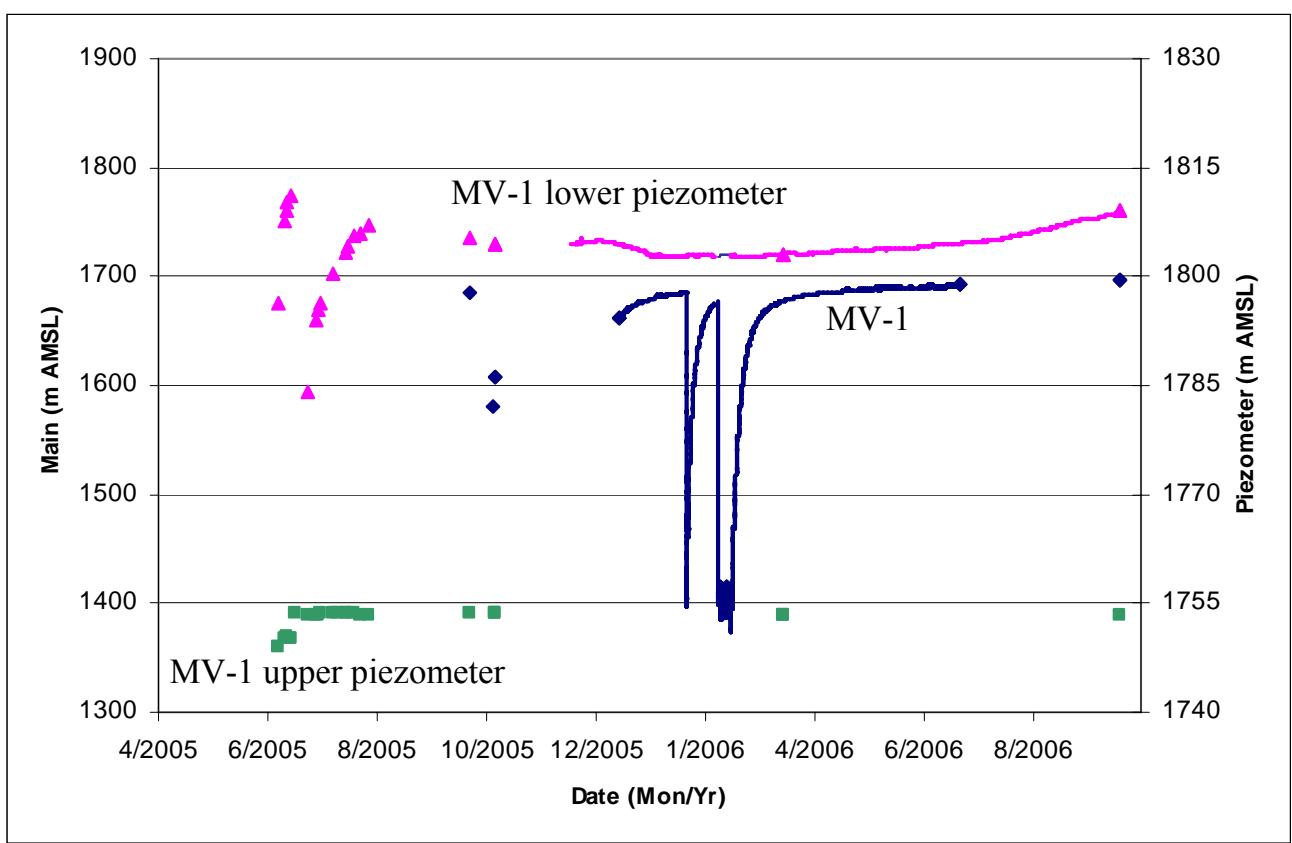

Figure 4. CNTA well MV-1 hydraulic head (meters above mean sea level) versus time (solid lines are from pressure transducer readings, periodic water level tags are shown with marker symbols: MV-1, diamond; MV-1 upper piezometer, square; and MV-1 lower piezometer, triangle). 


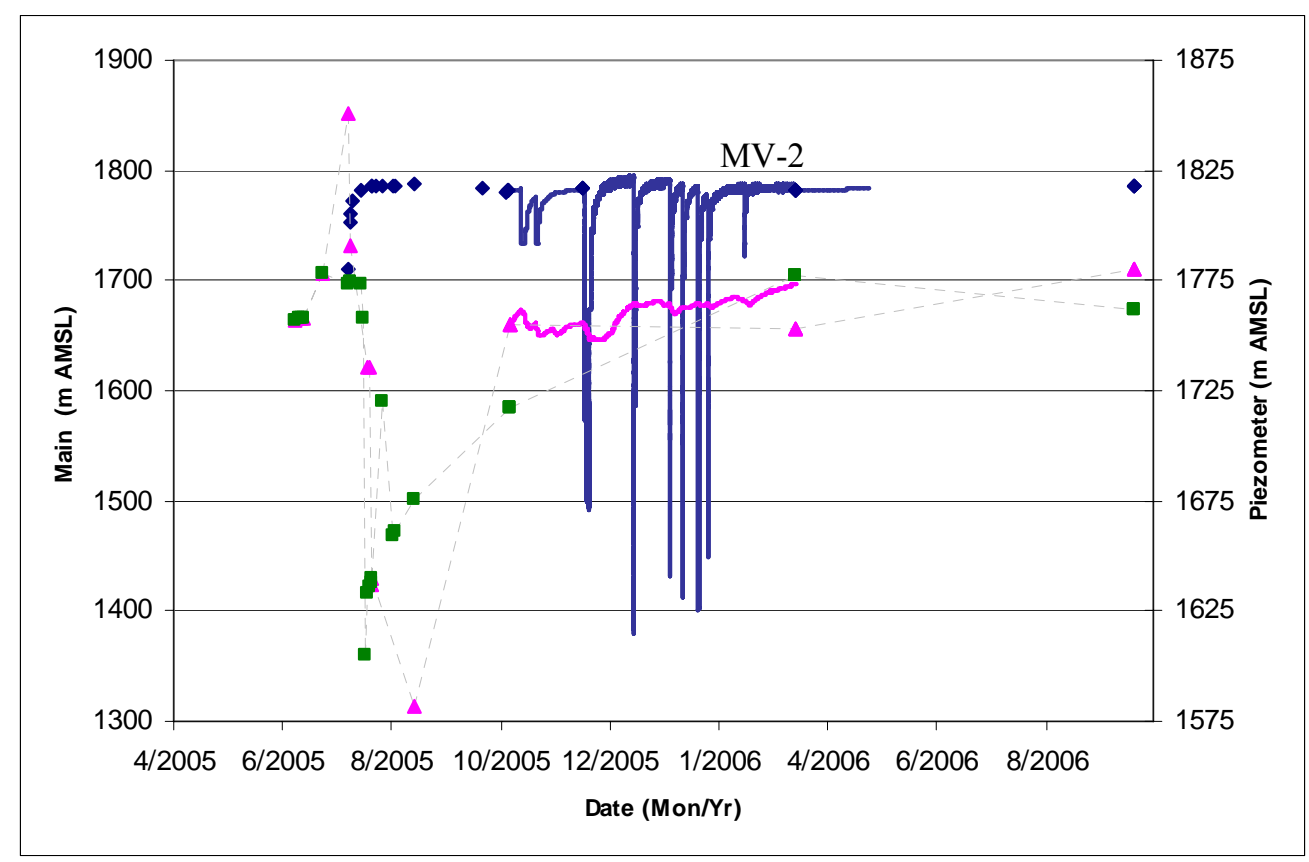

Figure 5. CNTA well MV-2 hydraulic head (meters above mean sea level) versus time (solid lines are from pressure transducer readings, periodic water level tags are shown with marker symbols: MV-2, diamond; MV-2 upper piezometer, square; and MV-2 lower piezometer, triangle).

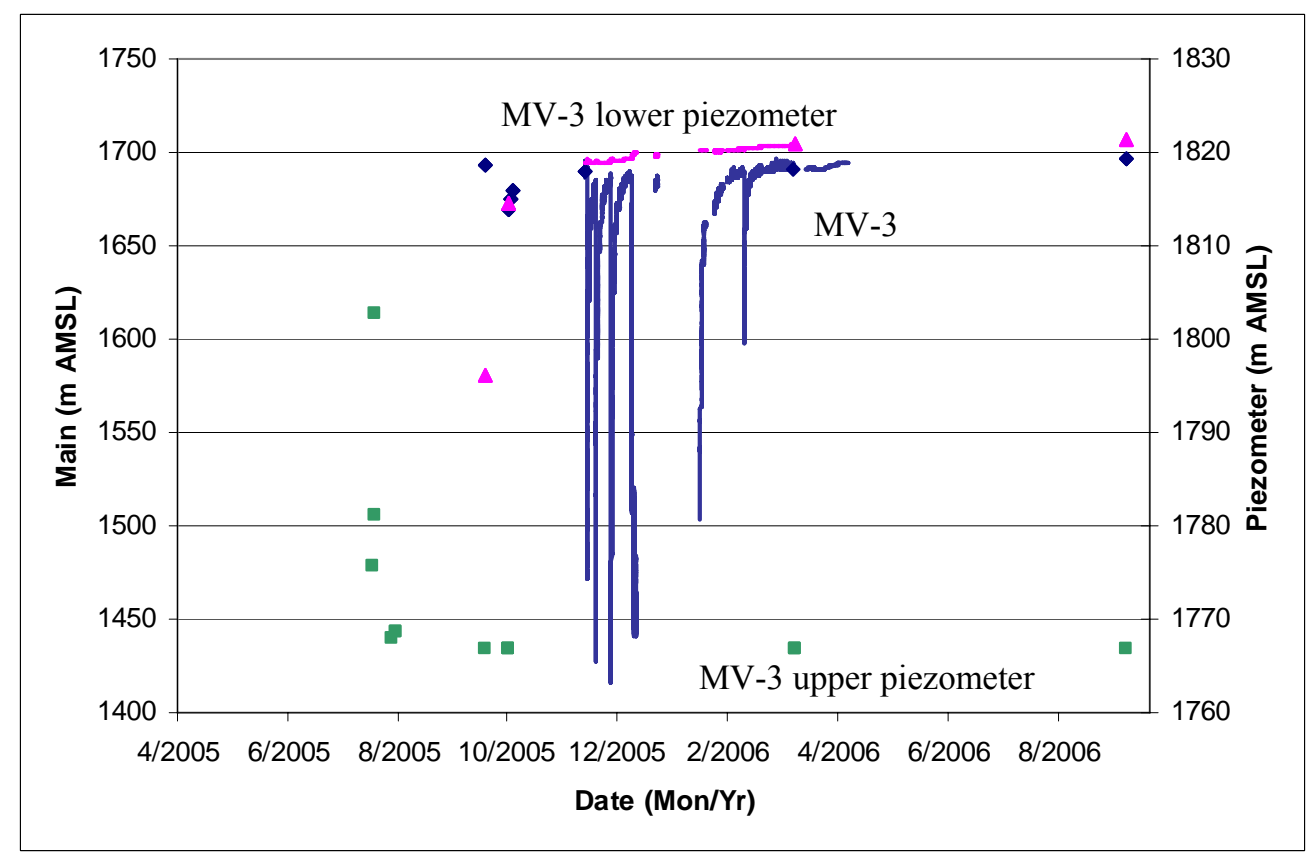

Figure 6. CNTA well MV-3 hydraulic head (meters above mean sea level) versus time (solid lines are from pressure transducer readings, periodic water level tags are shown with marker symbols: MV-3, diamond; MV-3 upper piezometer, square; and MV-3 lower piezometer, triangle). 


\section{Radioisotopic Results}

The radiochemical monitoring analytes specified by the CNTA CADD-CAP are tritium, carbon-14, and iodine-129. Tritium is identified as the primary radiochemical analyte based on its mobility in groundwater, its abundance in the source term for the first hundred years, and the low detection limit available. Tritium has a relatively short half-life (12.3 years), and the CADD-CAP recognizes that longer-lived radionuclides will gain in importance during post-closure monitoring. Carbon-14 and iodine-129 are specified as longlived radionuclides for the monitoring program because they are both important in defining the contaminant boundary (Pohll et al., 2003). Although carbon-14 and iodine-129 are identified for later post-closure monitoring, the CADD-CAP suggests that data collected preclosure (during the proof-of-concept period) can be used to establish baseline conditions.

Safe Drinking Water Act (EPA, 2000) radionuclide limits equate to concentrations of $20,000 \mathrm{pCi} / \mathrm{L}$ for tritium, 2,000 $\mathrm{pCi} / \mathrm{L}$ for carbon-14, and $1 \mathrm{pCi} / \mathrm{L}$ for iodine- 129 (the limit is specified as 0.04 millisievert per year as the total annual dose equivalent to an organ or the whole body that cannot be exceeded from internal exposure to beta particle and photon radioactivity, requiring calculation of dose equivalents and assumptions of consumption rate for determining activity-concentration limits). The detection limits required in the CADDCAP for the CNTA monitoring samples are $300 \mathrm{pCi} / \mathrm{L}$ for tritium, $5 \mathrm{pCi} / \mathrm{L}$ for carbon-14, and $0.1 \mathrm{pCi} / \mathrm{L}$ for iodine-129. The detection limit for tritium is well below the regulatory limit, but suitable for cost-effective nonenriched analysis. The low detection limits for carbon-14 and iodine-129 are specified during the proof-of-concept period to establish background conditions for comparison during post-closure monitoring.

The analytical results from the groundwater samples collected in February and March 2006 are all many orders of magnitude below the regulatory limits for tritium, carbon-14, and iodine-129 (Table 3). Quality assurance data, including replicate analyses, can be found in Appendix B. The tritium, carbon-14, and iodine-129 analyses for samples collected in September 2006 are comparable to the earlier results.

Table 3. CNTA MV well purge data and radiochemistry results.

\begin{tabular}{ccccccccc}
\hline $\begin{array}{c}\text { Well } \\
\text { Name }\end{array}$ & Date & $\begin{array}{c}\text { Volume } \\
\text { Pumped } \\
(\mathrm{L} / \mathrm{gal})\end{array}$ & $\begin{array}{c}\text { Temp } \\
\left({ }^{\circ} \mathrm{C}\right)\end{array}$ & $\begin{array}{c}\mathrm{EC} \\
(\mu \mathrm{S})\end{array}$ & $\mathrm{pH}$ & $\begin{array}{c}\text { Carbon-14 } \\
(\mathrm{pCi} / \mathrm{L})\end{array}$ & $\begin{array}{c}\text { Iodine-129 } \\
(\mathrm{pCi} / \mathrm{L})\end{array}$ & $\begin{array}{c}\text { Tritium } \\
(\mathrm{pCi} / \mathrm{L})\end{array}$ \\
\hline MV-1 & $2 / 14 / 2006$ & $8,346 / 2,205$ & 19 & 774 & 9.88 & $(1.12 \pm 0.05) \mathrm{E}-2$ & $(1.5 \pm 0.1) \mathrm{E}-7$ & $<3$ \\
& $9 / 21 / 2006$ & $4,243 / 1,121$ & 22.5 & 1,019 & 9.55 & $(5.61 \pm 0.10) \mathrm{E}-2$ & $(2.9 \pm 0.4) \mathrm{E}-7$ & $<45$ \\
MV-2 & $3 / 16 / 2006$ & $15,315 / 4,046$ & 20.3 & 908 & 10.05 & $(9.92 \pm 0.06) \mathrm{E}-2$ & $(2.6 \pm 0.1) \mathrm{E}-7$ & $<3$ \\
& $9 / 22 / 2006$ & $11,772 / 3,110$ & 21.5 & 1,097 & 10.38 & $(1.30 \pm 0.06) \mathrm{E}-2$ & $(2.6 \pm 0.3) \mathrm{E}-7$ & $<45$ \\
MV-3 & $3 / 16 / 2006$ & $5,042 / 1,332$ & 23 & 651 & 8.57 & $(3.95 \pm 0.01) \mathrm{E}-2$ & $(2.1 \pm 0.1) \mathrm{E}-7$ & $<3$ \\
& $9 / 22 / 2006$ & $5,303 / 1,401$ & 22.8 & 653 & 8.66 & $(5.11 \pm 0.01) \mathrm{E}-2$ & $(2.2 \pm 0.3) \mathrm{E}-7$ & $<45$ \\
\hline
\end{tabular}

\section{Monitoring Results Summary}

During FY 2006, the hydraulic heads in the CNTA MV wells were still recovering from drilling, testing, and sampling activities. Based on the low hydraulic conductivities found in these wells, it may take several years for the heads to equilibrate. No radioactivity above background was detected in the CNTA MV wells, and no time-series trends were observed. 


\section{REFERENCES}

Federal Facility Agreement and Consent Order, 1996 (as amended). Agreed to by the State of Nevada, the U.S. Department of Energy, and the U.S. Department of Defense.

Hassan, A.E., 2003. Long-term Monitoring Plan for the Central Nevada Test Area. Desert Research Institute, Division of Hydrologic Sciences Publication No. 45201.

Lyles, B. P. Oberlander, D. Gillespie, D. Donithan, and J. Chapman, 2006. Hydrologic Data and Evaluation for Wells near the Faultless Underground Nuclear Test, Central Nevada Test Area. Desert Research Institute, Division of Hydrologic Sciences Publication No. 45219.

Pohll, G., K. Pohlmann, J. Daniels, A. Hassan, and J. Chapman, 2003. Contaminant Boundary at the Faultless Underground Nuclear Test. Desert Research Institute Division of Hydrologic Sciences Report 45196, U.S. Department of Energy Nevada Operations Office report DOE/NV/13609-24, 49p.

U.S. Department of Energy (DOE), 1999. Corrective Action Investigation Plan for the Central Nevada Test Area Subsurface Sites (Corrective Action Unit No. 443), Rev. 1, DOE/NV-483-Rev 1. Nevada Operations Office, Las Vegas, NV.

U.S. Department of Energy (DOE), 2004. Corrective Action Decision Document/Corrective Action Plan for Corrective Action Unit 443: Central Nevada Test Area-Subsurface, Central Nevada Test Area, Nevada, DOE/NV-977. National Nuclear Security Administration, Las Vegas, NV.

U.S. Department of Energy (DOE), 2006. Well Installation Report for Corrective Action Unit 443, Central Nevada Test Area, Nye County, Nevada, DOE/NV-1102. National Nuclear Security Administration, Las Vegas, NV.

U.S. Environmental Protection Agency (EPA), 2000. Part II Environmental Protection Agency, 40 CFR Parts 9, 141 and 142: National Primary Drinking Water Regulations; Final Rule. Federal Register 65(236), 76708-76753 (December 7, 2000). 
THIS PAGE INTENTIONALLY LEFT BLANK 


\section{APPENDIX A. Well Completion Diagrams.}

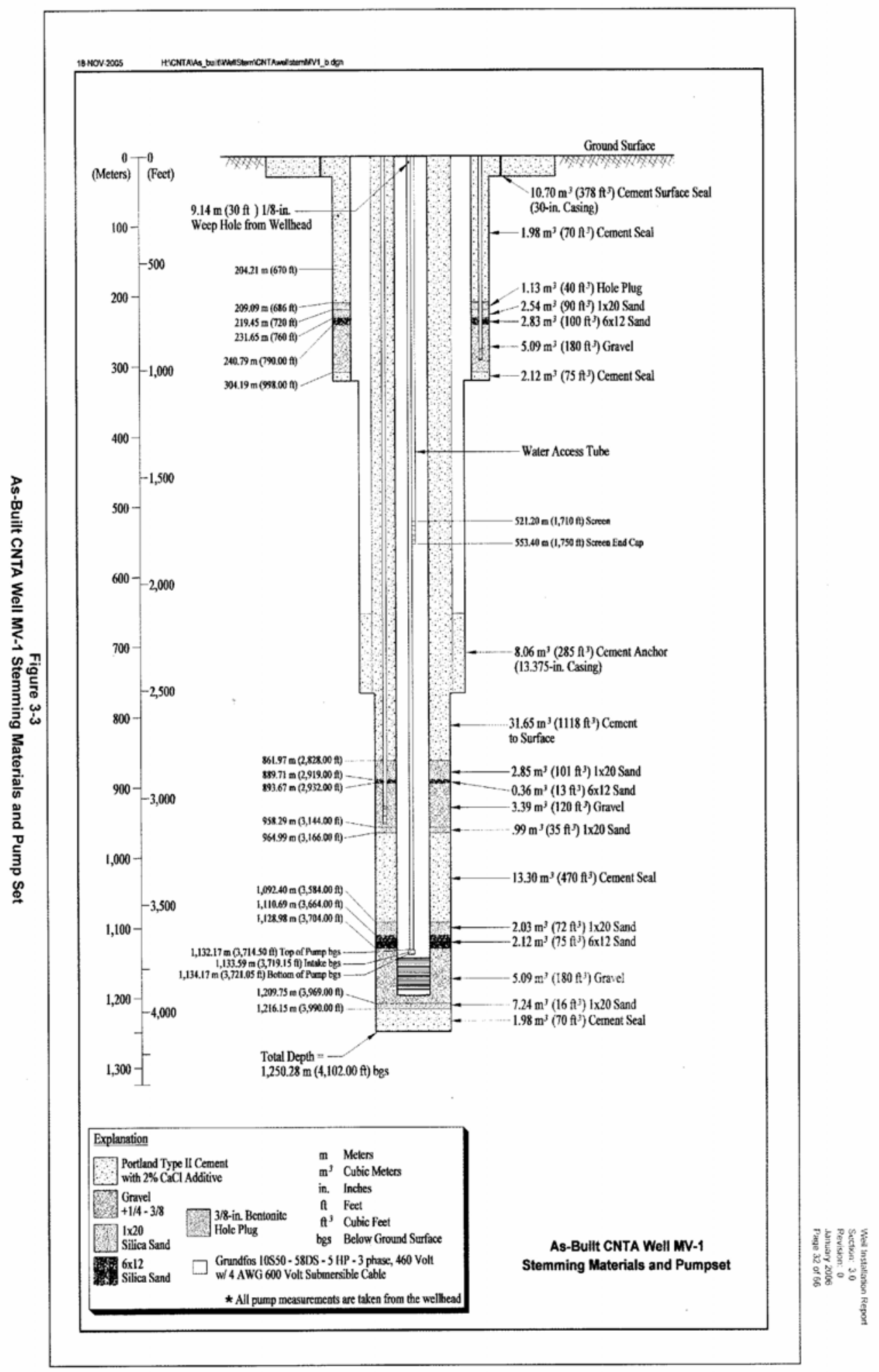

Figure A1. Schematic of Well MV-1 (from DOE, 2006). 


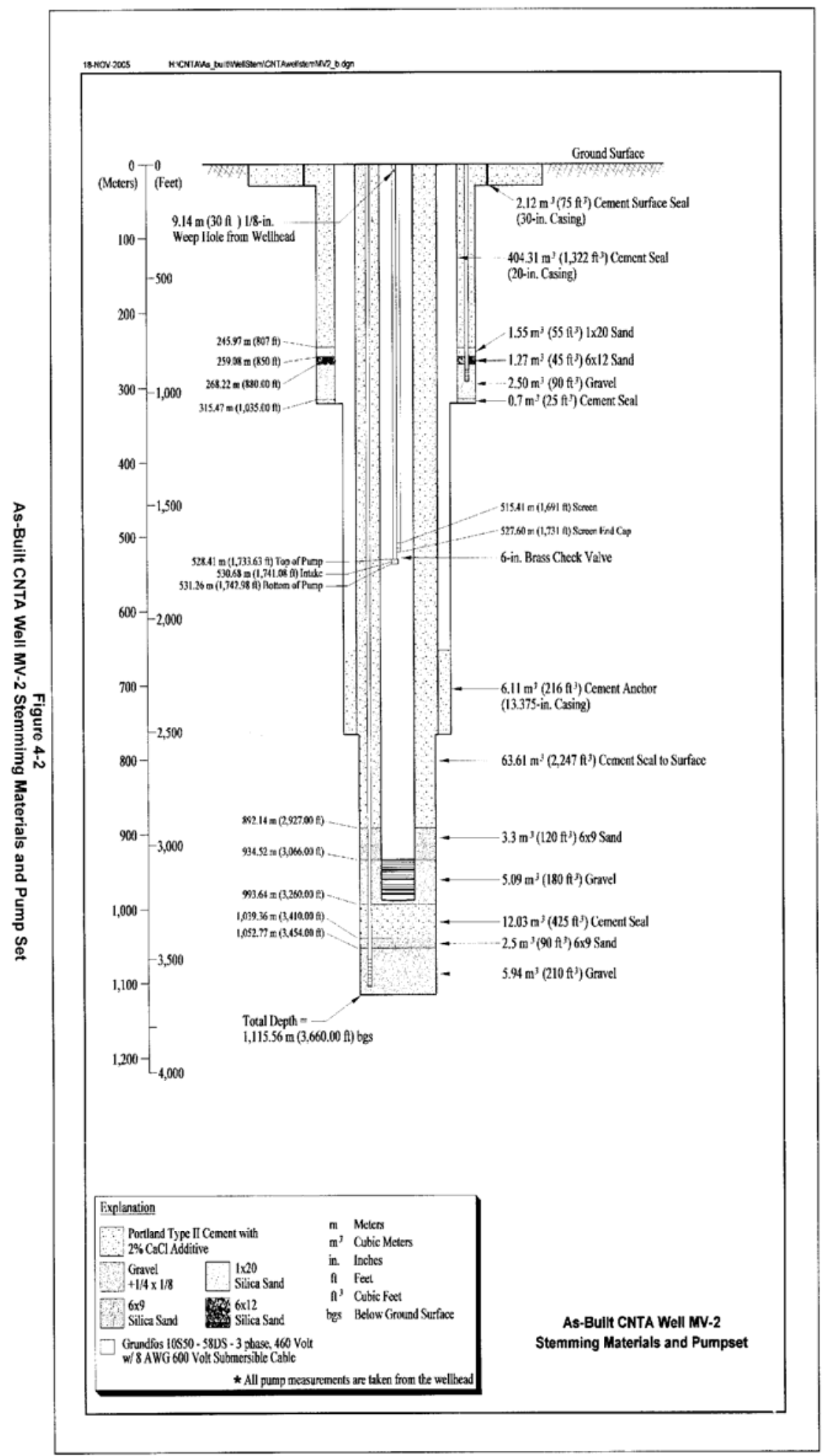

Figure A2. Schematic of Well MV-2 (from DOE, 2006). 


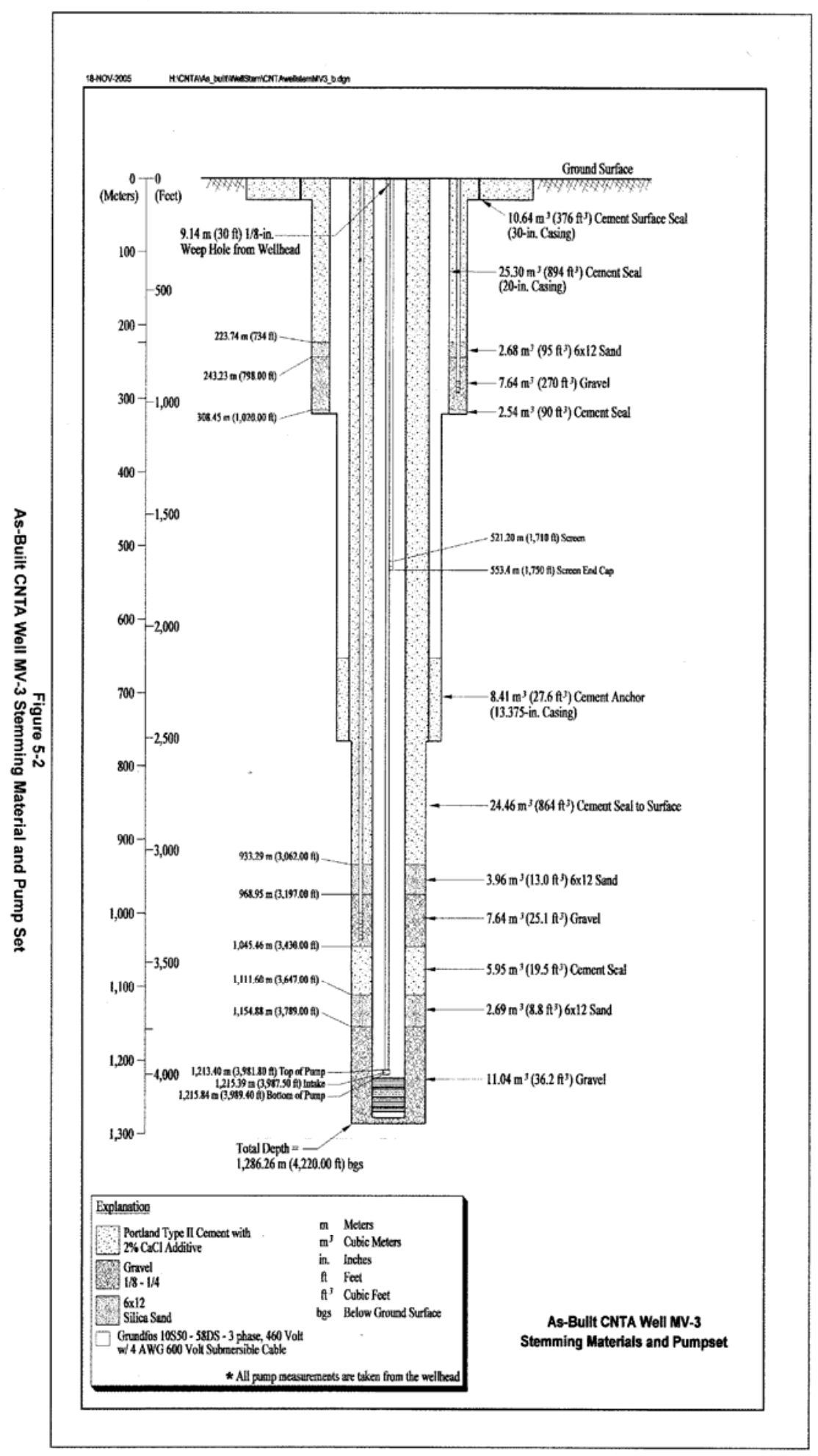

Figure A3. Schematic of Well MV-3 (from DOE, 2006). 
THIS PAGE INTENTIONALLY LEFT BLANK 


\section{APPENDIX B. Quality Assurance / Quality Control Data.}

Table B1. Iodine-129 analysis results (laboratory values were reported in atoms/L, activities were calculated assuming $1 \mathrm{E} 6$ atoms $/ \mathrm{L}=3.791 \mathrm{E}-8 \mathrm{pCi} / \mathrm{L}$ ).

\begin{tabular}{ccccc}
\hline Well Name & Sample Date & Time & $\begin{array}{c}129-\mathrm{I} \\
(\mathrm{x} \mathrm{10} \text { atoms } / \mathrm{L})\end{array}$ & $\left.\begin{array}{c}129-\mathrm{I} \\
(\mathrm{x} \mathrm{10})\end{array} \mathrm{pCi} / \mathrm{L}\right)$ \\
\hline MV-1 & $2 / 14 / 2006$ & $12: 30$ & $4.00 \pm 0.31$ & $1.51 \pm 0.118$ \\
MV-2 & $3 / 16 / 2006$ & $10: 54$ & $6.80 \pm 0.30$ & $2.58 \pm 0.114$ \\
MV-2 replicate & $3 / 16 / 2006$ & $10: 54$ & $4.46 \pm 0.27$ & $1.69 \pm 0.102$ \\
MV-3 & $3 / 16 / 2006$ & $13: 55$ & $5.54 \pm 0.27$ & $2.10 \pm 0.102$ \\
\hline
\end{tabular}

Table B2. Carbon-14 analysis results (laboratory values were reported in percent modern carbon (pmc), an $\mathrm{A}_{\mathrm{o}}$ (initial activity of carbon) of $13.56 \mathrm{dpm} / \mathrm{gm}$ C NBS OxI was used to convert pmc to $\mathrm{dpm} / \mathrm{gm} \mathrm{C}$, the $\mathrm{HCO}_{3}$ concentration was used to convert to $\mathrm{dpm} / \mathrm{L}$, assuming $3.7 \mathrm{E} 10 \mathrm{dps} / \mathrm{Ci}$ and $1 \mathrm{E} 12 \mathrm{pCi} / \mathrm{Ci}$, the carbon-14 was converted to $\mathrm{pCi} / \mathrm{L}$ ).

\begin{tabular}{|c|c|c|c|c|c|c|}
\hline Well Name & Sample Date & Time & $\begin{array}{l}\delta^{13} \mathrm{C} \\
(\%)\end{array}$ & $\begin{array}{l}{ }^{14} \mathrm{C} \\
(\mathrm{pmc})\end{array}$ & $\begin{array}{l}\mathrm{HCO}_{3} \\
(\mathrm{mg} / \mathrm{L}) \\
\end{array}$ & $\begin{array}{c}\mathrm{C} \\
(\mathrm{gm} / \mathrm{L})\end{array}$ \\
\hline MV-1 & $2 / 14 / 2006$ & $12: 30$ & -3.37 & $6.29 \pm 0.12$ & 147.5 & 0.02903 \\
\hline MV-1 replicate & $2 / 14 / 2006$ & $12: 30$ & -3.36 & $6.37 \pm 0.12$ & 146.5 & 0.02884 \\
\hline MV-1 replicate & $2 / 14 / 2006$ & $12: 30$ & -3.5 & $6.4 \pm 0.14$ & 142.5 & 0.02805 \\
\hline MV-2 & $3 / 16 / 2006$ & $10: 54$ & -2.34 & $3.93 \pm 0.11$ & 210 & 0.04134 \\
\hline MV-2 replicate & $3 / 16 / 2006$ & $10: 54$ & -2.23 & $3.55 \pm 0.10$ & 210 & 0.04134 \\
\hline MV-3 & $3 / 16 / 2006$ & $13: 55$ & -2.71 & $10.82 \pm 0.17$ & 304 & 0.05984 \\
\hline MV-1 & $9 / 21 / 2006$ & 10:00 & -3 & $27.33 \pm 0.21$ & 170.8 & 0.03363 \\
\hline MV-2 & $9 / 22 / 2006$ & $8: 30$ & -3.5 & $6.07 \pm 0.14$ & 177.7 & 0.03497 \\
\hline MV-3 & $9 / 22 / 2006$ & 10:01 & -3 & $14.37 \pm 0.17$ & 296.1 & 0.05828 \\
\hline Well Name & Sample Date & Time & $\begin{array}{c}{ }^{14} \mathrm{C} \\
(\mathrm{dpm} / \mathrm{gm})\end{array}$ & $\begin{array}{c}{ }^{14} \mathrm{C} \\
(\mathrm{dpm} / \mathrm{L}) \\
\end{array}$ & & \\
\hline MV-1 & $2 / 14 / 2006$ & $12: 30$ & 0.852704 & 0.0247581 & $1.12 \mathrm{~F}$ & $\pm 4.7 \mathrm{E}-4$ \\
\hline MV-1 replicate & $2 / 14 / 2006$ & $12: 30$ & 0.863549 & 0.024903 & $1.12 \mathrm{~F}$ & $\pm 4.7 \mathrm{E}-4$ \\
\hline MV-1 replicate & $2 / 14 / 2006$ & $12: 30$ & 0.867616 & 0.0243372 & $1.10 \mathrm{E}$ & $\pm 5.3 \mathrm{E}-4$ \\
\hline MV-2 & $3 / 16 / 2006$ & $10: 54$ & 0.53277 & 0.0220235 & $9.92 \mathrm{E}$ & $\pm 6.2 \mathrm{E}-4$ \\
\hline MV-2 replicate & $3 / 16 / 2006$ & $10: 54$ & 0.481256 & 0.019894 & $8.96 \mathrm{E}$ & $\pm 5.6 \mathrm{E}-4$ \\
\hline MV-3 & $3 / 16 / 2006$ & $13: 55$ & 1.466813 & 0.087776 & $3.95 \mathrm{E}$ & $\pm 1.4 \mathrm{E}-3$ \\
\hline MV-1 & $9 / 21 / 2006$ & $10: 00$ & 0.852704 & 0.0247581 & $1.12 \mathrm{~F}$ & $\pm 4.7 \mathrm{E}-4$ \\
\hline MV-2 & $9 / 22 / 2006$ & $8: 30$ & 0.863549 & 0.024903 & $1.12 \mathrm{~F}$ & $\pm 4.7 \mathrm{E}-4$ \\
\hline MV-3 & $9 / 22 / 2006$ & 10:01 & 0.867616 & 0.0243372 & $1.10 \mathrm{E}$ & $\pm 5.3 \mathrm{E}-4$ \\
\hline
\end{tabular}


Table B3. Field parameter stabilization measurements during well purge activities.

\begin{tabular}{|c|c|c|c|c|c|}
\hline Well Name & Date & Time & $\begin{array}{c}\text { Temperature } \\
\left({ }^{\circ} \mathrm{C}\right)\end{array}$ & $\begin{array}{c}\text { EC } \\
(\mu S)\end{array}$ & $\mathrm{pH}$ \\
\hline \multirow[t]{8}{*}{ MV-1 } & $2 / 14 / 2006$ & $11: 00$ & & 914 & 9.72 \\
\hline & $2 / 14 / 2006$ & $12: 00$ & & 912 & 9.89 \\
\hline & $2 / 14 / 2006$ & $13: 37$ & 19.8 & 774 & 9.88 \\
\hline & $9 / 21 / 2006$ & $9: 45$ & 14.7 & & \\
\hline & $9 / 21 / 2006$ & $9: 50$ & 16.5 & & \\
\hline & $9 / 21 / 2006$ & $9: 55$ & 18.8 & 1,028 & 10.05 \\
\hline & $9 / 21 / 2006$ & $10: 00$ & 22.5 & 1,006 & 9.62 \\
\hline & $9 / 21 / 2006$ & $10: 05$ & 24.0 & 1,019 & 9.55 \\
\hline \multirow[t]{7}{*}{ MV-2 } & $3 / 16 / 2006$ & $8: 44$ & 19.6 & & 10.04 \\
\hline & $3 / 16 / 2006$ & $9: 15$ & 20.3 & 923 & 10.11 \\
\hline & $3 / 16 / 2006$ & $10: 05$ & 18.0 & 941 & 10.10 \\
\hline & $3 / 16 / 2006$ & $10: 30$ & 20.3 & 908 & 10.05 \\
\hline & $9 / 22 / 2006$ & $8: 25$ & 21.5 & 1,104 & 10.32 \\
\hline & $9 / 22 / 2006$ & 8:29 & 21.4 & 1,090 & 10.37 \\
\hline & $9 / 22 / 2006$ & $8: 34$ & 21.5 & 1,097 & 10.38 \\
\hline \multirow[t]{5}{*}{ MV-3 } & $3 / 16 / 2006$ & $13: 50$ & 21.2 & 648 & 8.45 \\
\hline & $3 / 16 / 2006$ & $14: 18$ & 22.5 & 651 & 8.57 \\
\hline & $9 / 22 / 2006$ & $9: 55$ & 22.1 & 650 & 8.42 \\
\hline & $9 / 22 / 2006$ & $9: 57$ & 22.8 & 650 & 8.60 \\
\hline & $9 / 22 / 2006$ & 10:01 & 22.8 & 653 & 8.66 \\
\hline
\end{tabular}

Table B4. Tritium analysis results. (Scans of the initial samples were performed to determine radioactivity [detection limit $1,000 \mathrm{pCi} / \mathrm{L}$ ], unenriched analyses were then performed on samples and duplicates [detection limit $300 \mathrm{pCi} / \mathrm{L}$ or less], and enriched analyses were performed on the initial samples to establish baseline values.)

\begin{tabular}{cccccc}
\hline Well Name & Sample Date & Time & $\begin{array}{c}\text { Tritium Scan } \\
(\mathrm{pCi} / \mathrm{L})\end{array}$ & $\begin{array}{c}\text { Tritium } \\
\text { unenriched } \\
(\mathrm{pCi} / \mathrm{L})\end{array}$ & $\begin{array}{c}\text { Tritium } \\
\text { enriched } \\
(\mathrm{pCi} / \mathrm{L})\end{array}$ \\
\hline MV-1 & $2 / 14 / 2006$ & $12: 30$ & $<1,000$ & $<300$ & $<3$ \\
MV-2 & $3 / 16 / 2006$ & $10: 54$ & $<1,000$ & $<300$ & $<3$ \\
MV-2 replicate & $3 / 16 / 2006$ & $10: 54$ & & $<300$ & $<3$ \\
MV-3 & $3 / 16 / 2006$ & $13: 55$ & $<1,000$ & $<300$ & \\
MV-1 & $9 / 21 / 2006$ & $10: 00$ & & $<45$ & \\
MV-2 & $9 / 22 / 2006$ & $8: 30$ & & $<45$ & $<45$ \\
MV-3 & $9 / 22 / 2006$ & $10: 01$ & & $<5$ & \\
\hline
\end{tabular}




\section{DISTRIBUTION}

Jenny Chapman

Division of Hydrologic Sciences

Desert Research Institute

755 East Flamingo Road

Las Vegas, NV 89119-7363

Tim Echelard

Stoller-Navarro Joint Venture

7710 W. Cheyenne

Las Vegas, NV 89128

Kenneth A. Hoar, Director

Environment, Safety and Health Division

Nevada Site Office

National Nuclear Security Administration

U.S. Department of Energy

P.O. Box 98518

Las Vegas, NV 89193-8518

Richard Hopper

Deputy Laboratory Director

U.S. Environmental Protection Agency

Radiation and Indoor Environments

National Laboratory

4220 S. Maryland Parkway, Bldg. C

Las Vegas, NV 89119

Bruce Hurley

Hydrology Program Manager

Environment, Safety and Health Division

Nevada Site Office

National Nuclear Security Administration

U.S. Department of Energy

P.O. Box 98518

Las Vegas, NV 89193-8518

Rick Hutton

Stoller Grand Junction

2597 B 3 / 4 Road

Grand Junction, CO 81503
John Jones

Environmental Restoration Division

Nevada Site Office

National Nuclear Security Administration

U.S. Department of Energy

P.O. Box 98518

Las Vegas, NV 89193-8518

Marjory Jones

Division of Hydrologic Sciences

Desert Research Institute

2215 Raggio Parkway

Reno, NV 89512-1095

Randy Laczniak

U.S. Geological Survey

Water Resources Division

160 N. Stephanie St.

Henderson, NV 89074-8829

Tom Pauling

Office of Land and Site Management

Office of Legacy Management

U.S. Department of Energy

25973 / 4 Road

Grand Junction, CO 81503

Peter Sanders

Environmental Restoration Division

Nevada Site Office

National Nuclear Security Administration

U.S. Department of Energy

P.O. Box 98518

Las Vegas, NV 89193-8518

Reina Serino, Contracting Specialist

Office of Business Services

NNSA Service Center

Pennsylvania and H Street, Bldg. 20388

P.O. Box 5400

Albuquerque, NM 87185-5400 
David Shafer

Division of Hydrologic Sciences

Desert Research Institute

755 E. Flamingo Road

Las Vegas, NV 89119-7363

Jacqueline Van Lier

Stoller-Navarro Joint Venture

7710 W. Cheyenne

Las Vegas, NV 89128

Janet Appenzeller-Wing, Director

Environmental Restoration Division

Nevada Site Office

National Nuclear Security Administration

U.S. Department of Energy

P.O. Box 98518

Las Vegas, NV 89193-8518

Nevada State Library and Archives

State Publications

100 North Stewart Street

Carson City, NV 89710-4285

Archives

Getchell Library

University of Nevada, Reno

DeLaMare Library/262

University of Nevada, Reno

Document Section, Library

University of Nevada, Las Vegas

4505 Maryland Parkway

Las Vegas, NV 89154
Library

Stoller-Navarro Joint Venture

7710 W. Cheyenne, Bldg. 3

Las Vegas, NV 89128

Library

Southern Nevada Science Center

Desert Research Institute

755 E. Flamingo Road

Las Vegas, NV 89119-7363

Technical Library

Nevada Site Office

National Nuclear Security Administration

U.S. Department of Energy

P.O. Box 98518

Las Vegas, NV 89193-8518

Public Reading Facility

c/o Nuclear Testing Archive

Nevada Site Office

National Nuclear Security Administration

U.S. Department of Energy

P.O. Box 98521, M/S 400

Las Vegas, NV 89193-8521

Office of Scientific and Technical Information

U.S. Department of Energy

P.O. Box 62

Oak Ridge, TN 37831-9939

(electronic copy) 